\title{
Thrombolytic therapy use in peripheries of KPK
}

IKRAMULLAH ${ }^{1}$, ASFANDIYAR ${ }^{2}$, MATIULLAH KHAN ${ }^{3}, J_{A V A I D U L L A H^{4}}$, ABDUL SALAR KHAN ${ }^{5}$, MUHAMMAD MUSHTAQ $^{6}$

${ }^{1}$ Assistant Professor of Cardiology, ${ }^{2}$ District Cardiologist, ${ }^{6}$ Professor of Cardiology, Mardan Medical Complex Mardan

${ }^{3}$ District Cardiologist DHQ Teaching Hospital Swabi

${ }^{4,5}$ Cardiologists, Hyatabad Medical Complex Peshawar

Correspondence to Dr. Ikramullah Email: ikramcardio@yahoo.com Cell: 03134774433

\begin{abstract}
Aim: To find the frequency of thrombolytic therapy administration in acute ST elevation myocardial infarction in peripheral hospital of KPK

Study Design: Descriptive cross sectional study

Place \& Duration: DHQ Hospital Timergara District Dir Lower from $1^{\text {st }}$ January 2017 to $31^{\text {st }}$ December 2017.

Methods: Two hundred and sixty one patients with acute ST elevation myocardial infarction were included. Acute STEMI was defined as typical chest pain and $\geq 1 \mathrm{~mm}$ ST elevation in two consecutive leads.

Results: Mean age was $60 \pm 8$ years (28-90 years). Anterior MI was more common accounting for $56 \%$ of total study population. Male patients were 156 (59.7\%). 66.4\% were thrombolysed and remaining were deprived of the therapy.

Conclusion: Though in the developed countries primary $\mathrm{PCl}$ is used for STEMI but in our peripheral hospitals even most patients are still not thrombolysed properly.

Keyword: Thrombolysis, STEMI, Myocardial infarction
\end{abstract}

\section{INTRODUCTION}

James Herrick in 1912 did autopsy studies and found that thrombus in coronaries was the cause behind myocardial infarction 1 . Till for next 68 years still it was not sure and it was a disputed issue for long. In 1980 DeWood was the person who confirmed that thrombus is the main reason behind myocardial infarction causing obstruction to blood flow in coronaries and leads to myocardial infarction and the ultimate management is to remove or lyse the clot to restore myocardial blood supply².

Treatment of myocardial infarction is to lyse the clot through use of thrombolytic therapy which was the sole treatment for so long and still used in most of the cardiology centers where facility for primary $\mathrm{PCl}$ is not available. Fletcher in 1958 first time use thrombolytic therapy. ${ }^{3}$ Initially most of cardiology trials were performed on streptokinase. ${ }^{4}$ In 1969, first time intracoronary streptokinase was use by Chazov who was a Russian cardiologist $^{5}$ Rentrop et al $^{6}$ further studied and proved the effectiveness of streptokinase which further increased interest in thrombolytic therapy.

The aim behind use of thrombolytic use is to lyse clot and maintain blood supply to myocardium. Different studies showed mortality and morbidity benefits with thrombolytics like GUSTO-I. ${ }^{7}$ TIMI grade at 90 minutes is having strong association with 30 days mortality, for example it has been shown that mortality with 0 or 1 flow $^{8}$ is $8.9 \%$ and grade 3 flow is having $4.0 \%$ mortality.GISSI- $1^{9}$ also found $51 \%$ mortality reduction whereas ISIS- $3^{10}$ showed $48 \%$ reduction in mortality. Shortly the early thrombolytic administration more is mortality. ${ }^{11}$ This study will highlight the use of streptokinase and will give idea about hesitancy of its use and late presentation of patients to hospitals and delay or no use of thrombolytics.

Received on 14-08-2019

Accepted on 24-05-2020

\section{MATERIALS AND METHODS}

This was a descriptive cross sectional study performed at District Head Quarter Hospital Timergara, lower Dir KPK Pakistan. Data collection was done from 1.1.2017 to 31.12.2017. Patients admitted to cardiology unit of this hospital with Acute ST elevation myocardial infarction (STEMI) were included in the. Acute STEMI was defined per standard definition as typical chest pain and $\geq 1 \mathrm{~mm}$ ST elevation in two consecutive leads. After taking history and doing proper examination, detail interview was taken about risk factors. SPSS 20 was used for analysis of Data.

\section{RESULTS}

Mean age was $60 \pm 8$ years (28-90 years). Anterior MI was more common accounting for $56 \%$ of total study population, Inferior Ml was found in $41 \%$, Lateral $\mathrm{Ml}$ in $3 \%$ patients (Fig. 1). Out of total, $59.7 \%$ patients were male and remaining were female. Out of total patients, $66.4 \%$ were thrombolysed and remaining was deprived of the therapy (Table 2).

Fig. 1: myocardial infarction (MI)

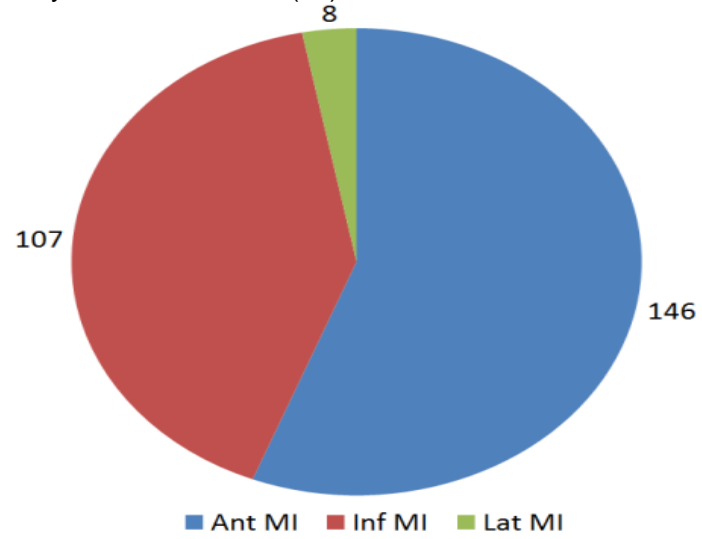


Table 1: Risk factors for myocardial infarction

\begin{tabular}{|l|c|c|}
\hline Risk factors & No. & $\%$ \\
\hline Mean Age (years) & \multicolumn{2}{|c|}{$60 \pm 8$} \\
\hline Gender (female) & 105 & 44.3 \\
\hline Hypertension & 156 & 59.7 \\
\hline Diabetes mellitus & 78 & 29.8 \\
\hline Hyperlipedemia & 104 & 39.8 \\
\hline Obese & 78 & 29.88 \\
\hline Smokers & 41 & 15.7 \\
\hline Family history & 91 & 34.8 \\
\hline
\end{tabular}

Table 2: Use of streptokinase in acute STEMI $(\mathrm{n}=261)$

\begin{tabular}{|l|c|c|}
\hline & No. & \%age \\
\hline Thrombolytic given & 176 & 66.4 \\
\hline No thrombolytics & 85 & 32.6 \\
\hline
\end{tabular}

\section{DISCUSSION}

This study was conducted in District Head Quarter Hospital Timergara. This hospital is the only hospital of the three districts where streptokinase is administered. Most of the patients either not reach here or come very late. This study shows that as compared to female myocardial infarction is more common in male gender than female $(40.3 \%$ vs $50.9 \%$ ) which is supported by multiple studies, for example study done by lqbal et $\mathrm{al}^{12}$ found similar $59 \%$ male patients.

We found that $66 \%$ of admitted patients receive streptokinase, similar reports were published by a study conducted in 2013 by Samieinasab et $\mathrm{al}^{13}$ which showed that $59 \%$ patient with acute STEMI received thrombolytic therapy, where as remaining did not received this therapy. This shows that still in developing countries people are even not receiving thrombolytic therapy properly where as in developed countries most of patients are receiving primary $\mathrm{PCl}$. Unfortunately we are not even using reteplase and alteplase in our hospitals though the world has gone beyond to the level of primary $\mathrm{PCl}$ in all cases of acute myocardial infarction. We are still relying on streptokinase which is almost obsolete in developed world and even in our peripheral hospitals it is not administered properly. .

\section{CONCLUSION}

Though in the developed countries primary $\mathrm{PCl}$ is used for STEMI but in our peripheral hospitals even most patients are still not thrombolysed properly.

\section{REFERENCES}

1. Herrick JB. Clinical features of sudden obstruction of the coronary arteries. JAMA 1912;59:2015-2020.

2. DeWood MA, Spores J, Notske R, Mouser LT, Burroughs R, Golden MS, Lang HT. Prevalence of total coronary occlusion during the early hours of transmural myocardial infarction. $\mathrm{N}$ Engl J Med 1980;303: 897-902.

3. Fletcher AP, Alkjaersig N, Smyrniotis FE, Sherry S. The treatment of patients suffering from early myocardial infarction with massive and prolonged streptokinase therapy. Trans Assoc Am Physicians 1958;71: 287-96.

4. Yusuf $S$, Collins R, Peto R, Furberg C, Stampfer MJ, Goldhaber SZ, Hennekens $\mathrm{CH}$. Intravenous and intracoronary fibrinolytic therapy in acute myocardial infarction: overview of results on mortality, reinfarction and side-effects from 33 randomized controlled trials. Eur Heart J 1985;6:556-85.

5. Chazov El, Matveeva LS, Mazaev AV, Sargin KE, Sadovskaia GV, Ruda MI. Intracoronary administration of fibrinolysin in acute myocardial infarct. Ter Arkh 1976;48:8-19.

6. Rentrop KP, Blanke $\mathrm{H}$, Karsch KR, Wiegand V, Kostering $\mathrm{H}$, Oster H, Leitz K. Acute myocardial infarction: intracoronary application of nitroglycerin and streptokinase. Clin Cardiol 1979;2:354-63.

7. Simes RJ, Topol EJ, Holmes DR Jr, White HD, Rutsch WR, Vahanian A, Simoons ML, Morris D, Betriu A, Califf RM, Ross AM, for the GUSTO-I Investigators. Link between the angiographic sub-study and mortality outcomes in a large randomized trial of myocardial reperfusion: importance of early and complete infarct artery reperfusion. Circulation 1995;91:1923-8.

8. Chesebro JH, Knatterud G, Roberts R, Borer J, Cohen LS, Dalen J, et al. Thrombolysis in Myocardial Infarction (TIMI) trial, phase I: a comparison between intravenous tissue plasminogen activator and intravenous streptokinase: clinical findings through hospital discharge. Circulation 1987; 76:14254.

9. Fibrinolytic Therapy Trialists' (FTT) Collaborative Group. Indications for fibrinolytic therapy in suspected acute myocardial infarction: collaborative overview of early mortality and major morbidity results from all randomised trials of more than 1000 patients. Lancet 1994;343:311-22.

10. ISIS-3 (Third International Study of Infarct Survival) Collaborative Group. ISIS-3: a randomised comparison of streptokinase vs tissue plasminogen activator vs anistreplase and of aspirin plus heparin vs aspirin alone among 41299 cases of suspected acute myocardial infarction. Lancet 1992;339:753-70.

11. Newby KL, Rutsch WR, Califf RM, Simoons ML, Aylward PE, Armstrong PW, Woodlief LH, Lee KL, Topol EJ, Van de Werf F, for the GUSTO-I Investigators. Time from symptom onset to treatment and outcomes after thrombolytic therapy. J Am Coll Cardiol 1996;27:1646-55.

12. Iqbal MA, Ikramullah, Hadi A, Farooq M, Khan N, Wahid I, et al. Frequency of conventional risk factors among coronary artery disease patients in tribal area of Pakistan. Pak Heart $\mathrm{J}$ 2014;47(3):132-6.

13. Samieinasab M, Shirani S, Hashemi SM, Pourmoghaddas A, Hekmat M. Non-administration of thrombolytic agents in acute myocardial infarction patients in Hajar hospital, Shahrekord, Iran: prevalence rate and causes. ARYA Atheroscler 2013; 9(1): 115-8. 